\title{
Testing a conceptual model of Facebook brand page communities
}

\begin{abstract}
Purpose

This research investigates consumer participation in Facebook brand page communities from the perspectives of uses and gratification theory and mass media dependency theory.
\end{abstract}

\section{Design/methodology/approach}

Data collection via an online survey resulted in 450 valid surveys where consumers indicated to what extent their motivations for Facebook use were socializing, entertainment, status seeking and information seeking. The sample included 358 respondents who had previously liked a brand on Facebook. These respondents were asked to provide the name of a brand they had liked on Facebook and answered questions regarding their experiences with the Facebook brand page for their self-identified brand.

\section{Findings}

Results indicate that motivation dimensions have differential effects at three different stages of consumer interaction with a Facebook brand page community. Socializing and information seeking are the primary reasons for initially joining a Facebook brand page community. After becoming a member of a Facebook brand page community, consumers require entertainment to keep them engaged. However, as consumers become more sophisticated, their involvement with a Facebook brand page and their frequency of posting on that page are dependent on their need for information. 


\section{Originality/value}

Insight is gained into the role of social media, specifically Facebook, in brand building. As theoretical frameworks that can guide branding practices using the social media channel are still in their infancy, this research makes an important contribution to the ongoing theoretical discussion. Additionally, the findings add to the online brand community literature by demonstrating the key drivers of consumer willingness to join and participate in a Facebook brand page community.

Key words: Facebook, motivation, brand community, involvement

Classification: Research paper 


\section{Testing a conceptual model of Facebook brand page communities}

\section{Introduction}

Social media sites such as Facebook offer brand managers great opportunity for brand advocacy (Wallace et al., 2012). As such, brand managers are embracing Facebook as a marketing channel to engage and mobilize consumers around their brands (Constantinides et al., 2008; Tsai and Men, 2014). However, despite the growth of social media, the benefits of social media marketing for business remain unclear (Divol et al., 2012). From a managerial perspective, it is imperative to understand what drives consumers to like a brand's Facebook page and what influences their willingness to contribute to the co-creation of value through their posting behavior in the Facebook site. Previous literature focuses on the impact of social media marketing activities on brand equity (Kim and Ko, 2012), brand advocacy (Wallace et al., 2012), and brand loyalty (Stokburger-Sauer, 2010). This research investigates participation behavior in a Facebook brand page community from the perspectives of Mass Media Dependency Theory and Uses and Gratification Theory.

The research aims to fill gaps in the literature by developing and testing a conceptual model of Facebook brand page community for brand managers. As much current Facebook research focuses on the use of Facebook as a communication tool for social interaction with friends (Ellison et al., 2007; Pempek et al., 2009; Ross et al., 2009), increasing the relevance of Facebook research to marketing requires an understanding of the factors that drive consumer integration into a Facebook brand page community (de Vries and Carlson, 2014; Stokburger-Sauer, 2010).

Despite brand managers’ perceived need to engage with social media such as Facebook, much remains unclear about the relationship between this medium and brand communities (de Vries and Carlson, 2014). As the development and empirical validation of 
the integration into brand community (IBC) concept occurred in offline brand communities (McAlexander et al., 2002; Ouwersloot and Odekerken-Schroder, 2008), this research applies the IBC concept to online brand communities, specifically brand communities arising through the Facebook brand page. Second, previous research has not specifically investigated the determinants of 'Liking' a Facebook brand page or posting on a brand’s Facebook page. Based on uses and gratifications theory (Blumler and Katz, 1974; Dholakia et al., 2004; Flanagin and Metzger, 2001) and the theory of media systems dependency (Ball-Rokeach and DeFleur, 1976), this research seeks to provide insights into a domain that is deficient in theoretical and empirical research. Figure 1 presents a theoretical framework.

-----Please insert Figure 1 about here-----

\section{Conceptual development}

\section{Liking a Facebook brand page}

Uses and gratifications theory is concerned with the way in which individuals use media and, as such, is an audience-centered approach to understanding mass communication. Developed in an effort to understand audience involvement with mass communication (Blumler, 1979) the theory has previously been applied to forms of mass media such as newspapers, radio and tv (Ruggiero, 2000). More recently this theory has been applied to newer forms of mass communication including the Internet (Papacharissi and Rubin, 2000) and social networking sites such as Facebook (Raacke and Bonds-Raacke, 2008). Lin (1996) argues that the strength of uses and gratification theory is its ability to allow researchers to study mediated communication situations via a single or multiple sets of psychological needs, psychological motives, communication channels, communication content, and psychological gratifications within a particular or cross-cultural context (p. 574). 
Media systems dependency theory views the media as an information system where the system resources impact the capacity of individuals to attain their goals (Ball-Rokeach, 1985; Grant et al., 1991). Whereas uses and gratification theory focuses on audience needs as drivers for media consumption, media dependency theory focuses on audience goals for media consumption (Ball-Rokeach and DeFleur, 1976). Media systems dependency theory implies a quasi-addictive relationship in that as an individual becomes increasingly dependent on media to satisfy their needs, the media becomes increasingly important to that individual. As a result, the media will have greater influence and effects on that individual. Considering both needs (uses and gratifications) and goals (media systems dependency) conceptualisations enables the development of a deeper understanding of consumer brand relationships in a social networking context such as Facebook.

The more an individual relies on Facebook to meet their needs, the more important Facebook will be to them and the more effects Facebook will have on that individual. Researchers have argued that the nature of an environment influences an individual's motivation to engage (Mehrabian and Russell, 1974). Facebook provides a unique online environment where users' gratifications include socializing, entertainment, informationseeking and status-seeking (Park et al., 2009). One means by which an individual may exhibit motivation to engage in the Facebook environment is by liking a brand. This leads to the following hypothesis:

H1: An individual's motivation to use Facebook will positively influence their liking of a brand on Facebook. 


\section{Integration into a Facebook brand page community}

Brand community refers to "a specialized, non-geographically bound community, based on a structured set of social relationships among admirers of a brand” (Muniz and O’Guinn, 2001 p. 412). While this definition was developed for an offline context, the "structured set of social relationships" is also a key defining characteristic in the online context of social media (Ouwersloot and Odekerken-Schroder, 2008; Park et al., 2009; Quinton and Harridge-March, 2010; Ross et al., 2009). The development of social media has significantly increased consumers' ability to engage in consumer-to-consumer interactions in an online context that transcends geographical limitations. These interactions have strong community-based emotional and social elements (Riegner, 2007) that parallel those of offline brand communities (Muniz and O’Guinn, 2001).

Social media enable consumers to exert greater influence on products and brands they consider for purchase (Riegner, 2007). In a reflection of this influence, researchers have proposed a new marketing paradigm: value co-creation (Payne et al., 2008; Prahalad and Venkat, 2004; Vargo and Lusch, 2004; Vargo et al., 2008). Customers can co-create value through brand communities by means of practices that (1) increase social networking among brand community members, (2) create favorable impressions of the brand in the social universe, (3) engage and reinforce members of the brand community, and (4) improve or enhance the use of the brand (Schau et al., 2009).

Another stream of research has adopted a customer-centric approach to understanding the dynamic nature of brand communities. The customer-centric approach emphasizes "the existence and meaningfulness of the community inherent in customer experience rather than ... the brand around which the experience revolves” (McAlexander et al., 2002, p. 39). Measurement of customer experience in brand communities led to the development of a scale measuring consumer integration into a brand community (IBC) consisting of four customer- 
centered relationships (McAlexander et al., 2002). Follow-up studies (McAlexander et al., 2003; Schouten et al., 2007) provide support for IBC in terms of a multifaceted nature of brand community and the way in which consumers engage with their brand community.

Not yet clear is the way in which an individual's motivation to use Facebook produces desirable effects such as consumer integration into a brand community (IBC). However, as motivation has been demonstrated to influence IBC it is anticipated that this relationship should also exist in the Facebook brand community context. This research represents an initial stage in understanding this.

H2: An individual's motivation to use Facebook will positively influence their integration into a Facebook brand page community.

\section{Involvement with a Facebook brand page}

Developed from social judgement theory (Sherif and Hovland, 1961), the concept of involvement has been used extensively in consumer behavior research (Costley, 1988). Rothschild (1984) defines involvement as a state of motivation, arousal, or interest that is influenced by past external variables and current internal variables (p. 217). Beatty et al., (1988) conceptualise different types of the involvement construct: ego involvement and purchase involvement. Purchase involvement results from consumer interaction with the purchase situation (Bloch and Richins, 1983) and the product (Beatty et al., 1988). Ego involvement, conceptually similar to enduring involvement (Laurent and Kapferer, 1985), relates to an ongoing interest with a product class rather than a specific purchase situation (Beatty et al., 1988). As this study investigates consumer involvement with a Facebook brand page, rather than a specific purchase situation, ego involvement is adopted. 
Ego involvement is a concept of interest in the online environment context. Wang et al., (2006) argue a positive relationship between consumer ego involvement and customer website loyalty while McMillan et al., (2003) find ego involvement to be positively related to consumer attitude toward a website. Implicit in these findings is a positive relationship between motivation and involvement. In the case of a Facebook brand page, and drawn from media systems dependency theory (Ball-Rokeach and DeFleur, 1976), as an individual's involvement with a Facebook brand page increases so too does their motivation to be involved and vice versa.

H3a: An individual's motivation to use Facebook will positively influence their involvement with a Facebook brand page.

H3b: An individual's integration into a Facebook brand page community will positively influence their involvement with a Facebook brand page.

\section{Posting on a Facebook brand page}

Posting is a participatory behavior (Men and Tsai 2012) in which individuals produce and publish their own content (e.g., comments, videos and pictures). Kabadayi and Price (2014) argue that posting or commenting is a highly visible behavior in Facebook brand page communities. Adopting this type of participatory behavior, individuals engage with the brand community via production. As posting is a variable that can be readily measured and reported, in this study it is used as a surrogate for participatory production behavior.

A relationship between user-participation and content production is argued to exist in the context of user-generated media with production argued to be the highest level of 
involvement (Shao 2009). As previously discussed, as an individual becomes increasingly dependent on media to satisfy their needs, the importance of that media to the individual will increase (Ball-Rokeach and DeFleur, 1976) and hence the motivation to undertake participatory behavior will also increase. This relationship has not yet been empirically investigated nor has it been explored in the context of social networking sites such as Facebook. However, as Facebook users generate considerable amounts of user-generated content, it is anticipated that in the Facebook context individuals' motivation and participation (integration and involvement) will positively influence content production (posting).

H4a: An individual's motivation to use Facebook will positively influence their posting on a Facebook brand page.

H4b: An individual's integration into a Facebook brand page community will positively influence their posting on the Facebook page for that brand.

H4c: An individual's involvement with a Facebook brand page will positively influence their posting on the Facebook page for that brand.

\section{Method}

\section{Sample and procedure}

A survey link was emailed to 1,114 individuals in Australia who had previously indicated their interest in participating in marketing research projects. The research process (refer Figure 2 for flowchart) process resulted in completion of 450 valid surveys, of which 358 had liked a brand and 92 had not. All participants $(\mathrm{N}=450)$ who acknowledged having a Facebook account answered questions regarding their motivations for using Facebook. Respondents 
who had liked a brand ( $\mathrm{n}=358$ ) entered the brand name into the survey and then answered questions regarding their experience with that brand's Facebook page. Table 1 provides a description of the research sample.

--- Insert Figure 2 about here ---

--- Insert Table 1 about here ---

\section{Survey instrument}

A review of the literature identified a number of pre-existing scales as being appropriate for the measurement of the constructs of this study. Previous investigations had validated these scales, although, other than motivations, not in the context of Facebook. We report the Cronbach's alphas, means, and standard deviations for the constructs in Table 2. We inspected the variables via measures of central tendency and dispersion to determine any departure from normality. As skew and kurtosis were within \pm 2 , data were deemed to be appropriate for the intended analyses (Hair et al., 2003).

--- Insert Table 2 about here ---

\section{Motivations for Facebook use}

The survey consisted of 13 items that related to four previously established motivations associated with Facebook use: socializing, entertainment, status seeking and information seeking (Park et al., 2009). The 13 items were measured on a five-point Likert scale ranging from 1 =strongly disagree to $5=$ strongly agree.

Integration into a Facebook brand page community 
Measures of integration into a Facebook brand page community consisted of adaptations from the IBC scale (McAlexander et al., 2002). The scale includes four customer-centric dimensions, namely customers-to-product, customers-to-brand, customers-to-company, and customers-to-other customers. Investigators have used the IBC scale to analyze relationships in diverse brand communities such as Jeep Jamboree participants (McAlexander et al., 2002; Schouten et al., 2007), loyalty members at a casino (McAlexander et al., 2003), and members of the Swatch Club (Ouwersloot and Odekerken-Schroder, 2008). This research extends previous investigations by adapting the concept of IBC to a wide variety of brands and brand page communities on Facebook. All measurements of items were on a five-point Likert scale ranging from $1=$ strongly disagree to $5=$ strongly agree.

\section{Involvement with a Facebook brand page}

Measures of involvement with a Facebook brand page were adaptations of Zaichowsky’s (1994) Personal Involvement Inventory (PII) and Macias’ (2003) measure of perceived level of interactivity of the website. Two reasons supported the decision to use the PII. First, PII measures the motivational state of involvement rather than involvement as a stable trait (Zaichkowsky, 1994). Second, PII is adaptable to different contexts, such as involvement with products, advertisements, or purchase situations (Zaichkowsky, 1994). Perceived interactivity includes two components: the ability of the person to get information online through surfing and researching and the ability to connect with other people via e-mail, chatrooms and social networking sites like Facebook (Macias, 2003). The survey used PII and perceived interactivity items on a seven-point semantic differential bipolar scale.

\section{Posting on a brand's Facebook page}


A single item (“How often do you post on [name of brand]'s Facebook page?”) measured the frequency of posting on a Facebook brand page by means of a seven-point Likert scale ranging from never (1) to daily (7).

\section{Analyses and results}

Determinants of 'Liking' a Facebook brand page (H1)

One objective of this study was to test the relationship between motivation and 'Liking' of a Facebook brand page (H1). To determine this logistic regression analyses were conducted where gender, age, and motivation for Facebook use were independent variables. Of the 450 possible cases for analyses, 8 respondents did not indicate their gender or age, and were removed from analyses.

Table 3 shows a significant model, $\chi^{2}(6, \mathrm{n}=442)=112.83, p<.001$. The model correctly classified 332 respondents who had liked a Facebook brand page, but misclassified 18 others (94.9\% of accuracy). The model also correctly classified 34 respondents who had not liked a Facebook brand page, but misclassified 58 others (37\% of accuracy). The overall accuracy of classification was, therefore, the weighted average of these two values (82.8\%) which is greater than a baseline model predicting all likes (79.5\%).

Significant predictors of 'Liking' a Facebook brand page were age $(b(.288)=-1.308$, $p<.001)$, socializing $(b(.231)=.767, p<.01)$, and information seeking $(b(.154)=.601$, $p<.001$ ). These results supported $\mathrm{H} 1$, but not all motivation dimensions were relevant to the decision of 'Liking' a Facebook brand page. For example, entertainment $(b(.156)=.289$, $p>.05)$ and status seeking $(b(.223)=-.311, p>.05)$ were found to be irrelevant.

Overall, the results show that respondents who were younger and more highly motivated to socialize and to seek information on Facebook were more likely to like a Facebook brand page. 
--- Insert Table 3 about here ---

\section{Motivation and IBC (H2)}

Prior to conducting analyses for the remaining hypotheses (H2 - H4), correlations between the variables were inspected (see Table 4).

--- Insert Table 4 about here ---

Multiple regression analyses were conducted to estimate the effects of motivation for Facebook use on IBC, which was operationalized by H2. Table 5 summarizes the results of the 4 models, representing the four dimensions of IBC.

The results show that entertainment $(\beta(.055)=.140, p<.05)$ and information seeking $(\beta(.041)=.228, p<.001)$ were significant predictors, accounting for a significant $10.8 \%$ of the variability in consumers-to-product relationships in a Facebook brand page community, $R^{2}=.108, F(4,353)=10.727, p<.001$. Similarly, it was found that entertainment $(\beta(.052)$ $=.132, p<.05)$ and information seeking $(\beta(.039)=.185, p<.01)$ also significantly influenced customers-to-brand relationships in a Facebook brand page community, $R^{2}=.086, F(4,353)$ $=8.342, p<.001$.

For customers-to-other consumers relationships, socializing $(\beta(.093)=.131, p<.05)$ and information seeking $(\beta(.051)=.194, p<.001)$ were significant predictors, $R^{2}=.094, F$ $(4,353)=9.145, p<.001$. Additionally, information seeking $(\beta(.050)=.243, p<.001)$ was the only significant predictor of customers-to-company relationships in a Facebook brand page community, $R^{2}=.093, F(4,353)=9.077, p<.001$. 
In general, these results supported H2. Status seeking had no effect on IBC although, by contrast, information seeking was a significant predictor of all four dimensions of IBC. Entertainment significantly influenced consumers-to-product and consumers-to-brand relationships. Finally, it was not surprising to find that socializing had a significant influence on consumers-to-other consumers relationships, but not on the other IBC dimensions.

--- Insert Table 5 about here ---

\section{Motivation and Involvement (H3a)}

Multiple regression analyses were conducted to estimate the effect of motivation for Facebook use on the respondent's involvement with a Facebook brand page (see Table 6). Of the 358 possible cases for analysis, 3 cases with missing values were removed. Table 6 shows that information seeking was the only significant predictor $(\beta(.066)=.341, p<.001)$, which accounted for a significant $13.2 \%$ of the variability in the level of involvement with a Facebook brand page, $R^{2}=.132, F(4,350)=13.354, p<.001$. This finding supported H3a. However, socializing $(\beta(.120)=.076, p>.05)$, entertainment $(\beta(.088)=.011, p>.05)$, and status seeking $(\beta(.100)=-.058, p>.05)$ were not significant in predicting the dependent variable.

--- Insert Table 6 about here ---

IBC and Involvement (H3b)

The hypothesis that IBC can significantly influence the respondent's involvement with a Facebook brand page (H3b) was tested via multiple regression analyses. Of the 358 possible cases for analyses, 3 cases were removed due to missing values. Table 7 shows that 
consumers-to-brand $(\beta(.142)=.321, p<.001)$, consumers-to-other consumers $(\beta(.076)=.230$, $p<.001)$, and consumers-to-company $(\beta(.080)=.161, p<.01)$ were significant IBC dimensions to predict the level of involvement with a Facebook brand page, whereas consumers-to-product $(\beta(.127)=-.054, p>.05)$ was non-significant. Overall, the model was significant, $R^{2}=.313, F(4,350)=39.835, p<.001$. H3b was supported.

--- Insert Table 7 about here ---

Determinants of posting on a brand's Facebook page (H4a, b, c)

Table 8 shows the use of hierarchical regression to examine the effects of the antecedent factors (motivation for Facebook use, integration into a Facebook brand page community (IBC), involvement with a Facebook brand page) on the frequency of posting on a Facebook brand page. Of the 358 possible cases for analyses, 11 cases with missing values were removed.

---Please insert Table 8 about here---

Initially, hierarchical regression analyses with gender and age were conducted , using the recently announced Facebook 2x2 segmentation strategy of women and men over 30 and under 30 (Delo, 2013). Additionally, an independent variable was created to represent the type of the brand the respondent had liked on Facebook; this variable was classified as product or service. The predicted antecedent factors were then added to the model in the following steps. A preliminary analysis indicated that multicollinearity for all sets of independent variable in the regression models was low (tolerance ranged from .29 to .99). 
As shown in Table 8, gender, age, and brand classification accounted for a significant $5.3 \%$ of the variance in the frequency of posting, $R^{2}=.053, F(3,343)=6.350, p<.001$. Both age $(\beta(.136)=.144, p<.01)$ and brand classification $(\beta(.132)=.145, p<.01)$ were found to be significant predictors in Model 1. The results indicate that older age rather than younger age, and service brand rather than product brand were associated with higher frequency of posting on a Facebook brand page.

On step 2, motivation for Facebook use was added to the regression equation, and accounted for an additional $7.3 \%$ of the variance in the frequency of posting, $\Delta R^{2}=.073, \Delta F$ $(4,339)=7.084, p<.001$. These results support H4a. In particular, information seeking $(\beta$ $(.059)=.280, p<.001)$ demonstrated a significant effect on the frequency of posting. Other motivation dimensions showed no significant effects on the dependent variable. In Model 2, age $(\beta(.133)=.141, p<.01)$ and brand classification $(\beta(.130)=.177, p<.01)$ were significant predictors.

Next, integration into a Facebook brand page community (IBC) was added to the model. Consistent with H4b, IBC accounted for a significant $11.9 \%$ of the variance in the frequency of posting, $\Delta R^{2}=.119, \Delta F(4,335)=13.233, p<.001$. Of the four IBC dimensions, consumers-to-product $(\beta(.120)=.173, p<.05)$ and consumers-to-other consumers $(\beta(.074)=.196, p<.01)$ significantly predicted the dependent variable of posting on a Facebook brand page. Other significant predictors in Model 3 were age $(\beta(.125)=.122$, $p<.05)$, brand classification $(\beta(.125)=.137, p<.01)$, and information seeking $(\beta(.058)$ $=.176, p<.01)$.

Finally, in accordance with H4c, involvement with a Facebook brand page was added to the regression equation, which explained a small but significant $0.9 \%$ of the variance in the frequency of posting, $\Delta R^{2}=.009, \Delta F(1,334)=4.208, p<.05$. As expected, involvement 
with a Facebook brand page $(\beta(.052)=.125, p<.05)$ was a significant predictor of the frequency of posting. In Model 4, other significant predictors were age $(\beta(.125)=.109, p$ $<.05)$, brand classification $(\beta(.127)=.115, p<.05)$, information seeking $(\beta(.060)=.143, p$ $<.05)$, consumers-to-product $(\beta(.119)=.179, p<.05)$ and consumers-to-other consumers $(\beta$ $(.074)=.179, p<.01)$ in Model 3. Overall, by Cohen’s (1988) conventions, a combined effect of the predictor variables in the regression model $\left(\boldsymbol{f}^{2}=.34\right)$ was considered 'medium' $\left(f^{2}=.35\right.$ can be considered 'large').

\section{Discussion}

The findings of this research provide interesting insights into the role of social media, specifically Facebook, in brand building. While brand managers are eager to develop an increasingly large Facebook fan base, a theoretical framework does not yet exist that can guide branding practices using the social media channel. Thus, this research is an important step in creating such a framework and finding the link between offline and online brand communities.

Online brand communities, in the context of this research, Facebook brand page communities, require action (fans to like a brand on Facebook) and participation (fans to post on the Facebook page for that brand). This research has added to the online brand community literature by demonstrating the key drivers of consumer willingness to join a Facebook brand page community and their participation in that community, using two main theoretical perspectives, namely mass media dependency theory (Ball-Rokeach and DeFleur, 1976) and uses and gratification theory (Blumler and Katz, 1974).

The research results support the conceptual model (refer Figure 1) by showing how Facebook user motivation influences consumer attitude and behavior in relation to a Facebook brand page community. First, as the research hypotheses anticipated, Facebook 
user motivation influences consumer willingness to join a Facebook brand page community (H1). However, only socializing and information seeking were found to be significant predictors of 'Liking' a brand on Facebook. A positive relationship was also evident between Facebook user motivation and IBC (H2). These results were mixed, suggesting that socializing was the only relevant motive for consumers-to-other consumers relationships, entertainment was related to consumers-to-product and consumers-to-brand relationships, and that information seeking was a significant predictor of all four IBC dimensions. When consumer involvement with a Facebook brand page was examined, information seeking was found to be the only significant motivator (H3a). Similarly, information seeking was the only significant motive for an individual to post on a Facebook brand page (H4a). Overall, these results have important implications. These results suggest that for Facebook users, their initial reasons for joining a Facebook brand page community are socializing and information seeking. After becoming a member of the Facebook brand page community, entertainment is also required to maintain community engagement. Ultimately, involvement with a Facebook brand page and frequency of posting on that page is dependent on an individual's need for information.

This study also increases the understanding of the nature of IBC as a customer-centric concept and the role of IBC in a Facebook brand page community. Whereas previous research investigates IBC in physical brand communities (McAlexander et al., 2002), this research demonstrates that IBC also occurs in virtual brand communities such as Facebook brand page communities. Additionally, it has been demonstrated that IBC influences brand loyalty (McAlexander et al., 2003; Stokburger-Sauer, 2010). This research increases that understanding by demonstrating the effects of IBC on consumer attitude (involvement with a Facebook brand page; H3b) and behavior (posting on a Facebook brand page; H4a) in online (Facebook) brand page communities. 
Previous investigators propose that brand communities are constantly evolving due to the fact that consumers are creating content often beyond that which the firm anticipates (Muniz and O’Guinn, 2001; Schau et al., 2009). Shao (2009) argues that consumers producing content represents the ultimate level of involvement with user generated media. Therefore, this study chose to focus on the behavior of posting on a Facebook brand page. Previous research has examined social influences (Dholakia, et al., 2004; Eisenbeiss et al., 2012), personality traits (Ross et al., 2009), and technological competence (Tsai et al., 2012) as antecedents of brand community participation. This research contributes to that body of knowledge by suggesting that consumers who are more embedded in a Facebook brand page community (H4b) and more involved with a Facebook brand page (H4c) tend to be more willing to post on the Facebook page for that brand.

\section{Managerial implications}

Increasingly, managerial discussions tend to focus on the potential of social media to enhance retail brands. For social media to have an impact on brand equity, brand managers must concentrate on building online brand communities (Schau et al., 2009). This research concurs with previous findings that IBC consists of four distinct dimensions: consumers-to-product, consumers-to-brand, consumers-to-other consumers, and consumers-to company. Therefore, to realize the full potential of IBC through a Facebook brand page, the brand manager must actively create a multi-dimensional customer experience on that page.

Brand managers should also be aware that for consumers, joining a Facebook brand page community, staying with that community, and creating (posting) content for that community may involve different types of motivations. Initial participation is based around socializing and information seeking motives. However, for individuals who have already liked a brand on Facebook, their engagement with that community appears to depend on the 
extent to which they can satisfy their entertainment needs as well as socializing and information seeking needs through that community. Although user motivation and experience may vary within a Facebook brand page community, the key determinant of whether a Facebook fan is an active creator of content or not is dependent on their need for information and whether or not that need is satisfied through that community.

Furthermore, brand managers should develop strategies to encourage their Facebook fans to increase the extent of posting, as frequency of posting affects brand knowledge and equity via brand community (Schau et al., 2009). For example, Zappos uses a "Fan of the Week" strategy to increase Facebook postings and Jones Soda gives its Facebook fans the opportunity to label the bottle with their own pictures, while Burt's Bees combines its Facebook page with the Bzzagent, a marketing program to encourage new product trial and consumer feedback. Although Facebook conversations are outside of the direct control of the brand manager, these exchanges must frame customer experiences in a way that is congruent with the image of the brand or brand meanings.

\section{Limitations and suggestions for future research}

The limitations of this research manifest in three ways. First, survey results depend on participants' ability to articulate attitudes and feelings appropriately within the constraints of the survey question. However, through analyses, the multiple item measures demonstrate construct validity and the strength of their psychometric properties. Second, the research sample comes from only one geographic region. However, consumers of western cultures are in many respects greatly similar, suggesting that the results may generalize with reasonable confidence to other regions, particularly the United States and the United Kingdom. Third, these research findings apply only to Facebook users. However, the vast number of Facebook users worldwide suggests that the results may generalize to other social media as well. This 
investigation opens avenues to a number of areas of further inquiry. For example, there is a clear need to develop future research to investigate the processes associated with building a community online and the details of how online brand communities operate. A longitudinal study could be used to better understand why consumers who have liked a Facebook page then decide to interact with the brand community in posting pictures and comments. Such research would uncover the determinants of interaction with the community at different stages of the consumer and brand relationship.

This research proposes a theoretical model toward an understanding of consumer interactions with a Facebook brand page community. Future investigations may extend the model to other brand-related social media channels, such as Twitter (Smith et al., 2012).

\section{Conclusion}

To successfully use Facebook as a marketing channel, brand managers must understand consumer interactions with a Facebook brand page community. This research proposes a conceptual framework that both marketers and researchers can use to understand Facebook brand page communities from a customer-centric perspective. The findings indicate that consumer brand relationship development in a social networking context such as Facebook requires understanding of both needs (uses and gratifications ) and goals (media system dependency). Future research may enable generalization of the research findings to other social media channels. 


\section{References}

Ball-Rokeach, S.J. (1985), “The origins of individual media-system dependency: a sociological framework”, Communication Research, Vol. 12 No. 4, pp. 485-510.

Ball-Rokeach, S.J. and DeFleur, M.L. (1976), “A dependency model of mass-media effects”, Communication Research, Vol. 3 No. 1, pp. 3-21.

Beatty, S.E., Homer, P. and Kahle, L.R. (1988), “The involvement-commitment model:

Theory and implications”, Journal of Business Research, Vol. 16 No. 2, pp. 149-167.

Bloch, P.H. and Richins, M.L. (1983), “A theoretical model for the study of product importance perceptions”, Journal of Marketing, Vol. 47 No. 3, pp. 69-81.

Blumler, J.G. (1979), “The role of theory in uses and gratifications studies”, Communication Research, Vol. 6 No. 1, pp. 9-36.

Blumler, J.G. and Katz, E. (1974), The uses of mass communications: Current perspectives on gratifications research, Sage, Beverly Hills, CA.

Cohen, J. (1988), Statistical power analysis for the behavioral sciences (2nd ed.), Erlbaum, Hillsdale, N.J.

Constantinides, E., Romero, C.L. and Gomez Boria, M.A. (2008), “Social media: A new frontier for retailers?”, European Retail Research, Vol. 22, pp. 1-28.

Costley, C.L. (1988), “Meta analysis of involvement research”, Advances in consumer research, Vol. 15 No. 1, pp. 554-562.

Delo, C. (2013), “Facebook Seeks 7-Figure Price Tag for Summer Debut of Video Ads”, Advertising Age available at: http://adage.com/article/digital/facebook-seeks-1million-price-tag-video-ads/240901/ (accessed 23 May, 2013).

De Vries, N.J. and Carlson, J. (2014), “Examining the drivers and brand performance implications of customer engagement with brands in the social media environment”, Journal of Brand Management, Vol. 21 No. 6, pp. 495-515. 
Dholakia, U.M., Bagozzi, R.P. and Pearo, L.K. (2004), “A social influence model of consumer participation in network - and small-group-based virtual communities”, International Journal of Research in Marketing, Vol. 21 No. 3, pp. 241-263.

Divol, R., Edelman, D. and Sarrazin, H. (2012), “Demystifying social media”, McKinsey Quarterly, Vol. 2, pp. 66-77.

Eisenbeiss, M., Blechschmidt, B., Backhaus, K. and Freund, P.A. (2012), “The (Real) World Is Not Enough: Motivational Drivers and User Behavior in Virtual Worlds”, Journal of Interactive Marketin , Vol. 26 No. 1, pp. 4-20.

Ellison, N.B., Steinfield, C. and Lampe, C. (2007), “The Benefits of Facebook "Friends”: Social Capital and College Students’ Use of Online Social Network Sites”, Journal of Computer-Mediated Communication, Vol. 12 No. 4, pp. 1143-1168.

Flanagin, A.J. and Metzger, M.J. (2001), “Internet use in the contemporary media environment”, Human communication research, Vol. 27 No. 1, pp. 153-181.

Grant, A.E., Guthrie, K. and Ball-Rokeach, S.J. (1991), “Television shopping: A media system dependency perspective”, Communication Research, Vol. 18 No. 6, pp. 773798.

Hair, J.F., Bush, R.P. and Ortinau, D. J. (2003), Marketing research within a changing information environment (2nd ed.), McGraw Hill/Irwin, Boston.

Kabadayi, S. and Price, K. (2014), “Comsumer - brand engagement on Facebook: liking and commenting behaviors”, Journal of Research in Interactive Marketing, Vol. 8 No. 3, pp. 203-223.

Kim, A.J. and Ko, E. (2012), “Do social media marketing activities enhance customer equity? An empirical study of luxury fashion brand”, Journal of Business Research, Vol. 65 No. 10, pp. 1480-1486. 
Laurent, G. and Kapferer, J. (1985), “Measuring consumer involvement profiles”, Journal of marketing research, Vol. 22 No. 1, pp. 41-53.

Lin, C.A. (1996), “Looking back: The contribution of Blumler and Katz's uses of mass communication to communication research”, Journal of Broadcasting \& Electronic Media, Vol. 40 No. 4, pp. 574-581.

Macias, W. (2003), “A preliminary structural equation model of comprehension and persuasion of interactive advertising brand web sites”, Journal of Interactive Advertising, Vol. 3 No. 2, pp. 36-48.

McAlexander, J.H., Kim, S.K. and Roberts, S.D. (2003), “Loyalty: The influences of satisfaction and brand community integration”, Journal of Marketing Theory and Practice, Vol. 11 No. 4, pp. 1-11.

McAlexander, J.H., Schouten, J.W. and Koening, H.F. (2002), “Building brand community”, Journal of Marketing, Vol. 66 No. 1, pp. 38-54.

McMillan, S.J., Hwang, J. and Lee, G. (2003), "Effects of structural and perceptual factors on attitudes toward the website”, Journal of Advertising Reseach, Vol. 43 No. 4, pp. 400409.

Mehrabian, A. and Russell, J.A. (1974), An approach to environmental psychology, MIT Press, Cambridge, MA.

Men, L.R. and Tsai, W.S. (2012), “Beyond liking or following: Understanding public engagement on social networking sites in China”, Public Relations Review, Vol. 39 No. 1, pp. 13-22.

Muniz, A.M.J. and O’Guinn, T.C. (2001), “Brand Community”, Journal of Consumer Research, Vol. 27 No. 4, pp. 412-432.

Ouwersloot, H. and Odekerken-Schroder, G. (2008), "Who's who in brand communities - and why?”, European Journal of Marketing, Vol. 42 No. 5/6, pp. 571-585. 
Papacharissi, Z. and Rubin, A. M. (2000), “Predictors of Internet use”, Journal of Broadcasting \& Electronic Media, Vol. 44 No. 2, pp. 175-196.

Park, N., Kee, K.F. and Valenzuela, S. (2009), “Being immersed in social networking environment: Facebook groups, uses and gratifications, and social outcomes”, CyberPsychology \& Behavior, Vol. 12 No. 6, pp. 729-733.

Payne, A.F., Storbacka, K. and Frow, P. (2008), “Managing the co-creation of value”, Journal of the Academy of Marketing Science, Vol. 36 No. 1, pp. 83-96.

Pempek, T.A., Yermolayeva, Y.A. and Calvert, S.L. (2009), “College students' social networking experiences on Facebook”, Journal of Applied Developmental Psychology, Vol. 30 No. 3, pp. 227-238.

Prahalad, C.K. and Venkat, R. (2004), “Co-creation experiences: The next practice in value creation”, Journal of Interactive Marketing, Vol. 18 No. 3, pp. 5-14.

Quinton, S. and Harridge-March, S. (2010), "Relationships in online communities: The potential for marketers”, Journal of Research in Interactive Marketing, Vol. 4 No. 1, pp. 59-73.

Raacke, J. and Bonds-Raacke, J. (2008), “MySpace and Facebook: Applying the uses and gratifications theory to exploring friend-networking sites”, CyberPsychology \& Behavior, Vol. 11 No. 2, pp. 169-174.

Riegner, C. (2007), "Word of mouth on the web: The impact of web 2.0 on consumer purchase decisions”, Journal of Advertising Research, Vol. 47 No. 4, pp. 436-447.

Ross, C., Orr, E.S., Sisic, M., Arseneault, J.M., Simmering, M.G. and Orr, R.R. (2009), “Personality and motivations associated with Facebook use”, Computers in Human Behavior, Vol. 25 No. 2, pp. 578-586.

Rothschild, M.L. (1984), "Perspectives on involvement: current problems and future directions”, Advances in consumer research, Vol. 11 No. 1, pp. 216-217. 
Ruggiero, T.E. (2000), “Uses and gratifications theory in the 21st century”, Mass communication \& society, Vol. 3 No. 1, pp. 3-37.

Schau, H.J., Muñiz, A.M. and Arnould, E.J. (2009), "How brand community practices create value”, Journal of Marketing, Vol. 73 No. 5, pp. 30-51.

Schouten, J.W., McAlexander, J.H. and Koenig, H.F. (2007), “Transcendent customer experience and brand community”, Journal of the Academy of Marketing Science, Vol. 35 No. 3, pp. 357-368.

Shao, G. (2009), “Understanding the appeal of user-generated media: a uses and gratification perspective”, Internet Research, Vol. 19 No. 1, pp. 7-25.

Sherif, M. and Hovland, C.I. (1961), Social judgment: Assimilation and contrast effects in communication and attitude change, Yale, New Haven.

Smith, A.N., Fischer, E. and Yongjian, C. (2012), "How does brand-related user-generated content differ across YouTube, Facebook, and Twitter?”, Journal of Interactive Marketing, Vol. 26 No. 2, pp. 102-113.

Stokburger-Sauer, N. (2010), “Brand community: Drivers and outcomes”, Psychology and Marketing, Vol. 27 No. 4, pp. 347-368.

Tsai, H., Huang, H. and Chiu, Y. (2012), “Brand community participation in Taiwan: Examining the roles of individual, group, and relationship-level antecedents”, Journal of Business Research, Vol. 65 No. 5, pp. 676-684.

Tsai, W.S. and Men, L.R. (in press), “Consumer engagement with brands on social network sites: A cross-cultural comparison of China and the USA”, Journal of Marketing Communications.

Vargo, S.L. and Lusch, R.F. (2004), “Evolving to a new dominant logic for marketing”, Journal of Marketing, Vol. 68 No. 1, pp. 1-17. 
Vargo, S.L., Maglio, P.P. and Akaka, M.A. (2008), “On value and value co-creation: A service systems and service logic perspective”, European Management Journal, Vol. 26 No. 3, pp. $145-152$.

Wallace, E., Isabel, B. and de Chernatony, L. (2012), “Facebook 'friendship' and brand advocacy”, Journal of Brand Management, Vol. 20 No. 2, pp. 128-146.

Wang, H., Pallister, J.G. and Foxall, G.R. (2006), “Innovativeness and involvement as determinants of website loyalty: II. Determinants of consumer loyalty in B2C ecommerce”, Technovation, Vol. 26 No. 12, pp. 1366-1373.

Zaichkowsky, J. L. (1994), “The personal involvement inventory: Reduction, revision, and application to advertising”, Journal of Advertising, Vol. 23 No. 4, pp. 59-70. 